Fethullah Gulen, Oleh: Aly Mashar

\title{
FETHULLAH GULEN DAN GERAKAN ISLAM TURKI KONTEMPORER
}

\begin{abstract}
Aly Mashar*
Fethullah Gulen adalah salah satu pemikir Muslim Turki kontemporer. Ia adalah seorang aktivis da'i, reformis, pemikir pendidikan, ekonom, dan juga tokoh penggagas dialog antar agama. Semangat gerakan dan gagasan Gulen ini dilahirkan dari pemahaman keagamaan Gulen yang moderatisisme. Ia mempertahankan nilai-nilai dan ajaran-ajaran dari khasanah klasik dan pula mengambil hal yang lebih baik dari khasanah modern.

Gerakan dan gagasan Gulen berhasil merubah kondisi masyarakat Turki, baik dari hal pendidikan, ekonomi, serta hubungan antar aliran dan umat beragama. Pengaruh ini tidak hanya berkutat di Turki, namun menyebar dan menjalar hampir ke seluruh negara di belahan dunia, termasuk Indonesia. Di Indonesia, Gulen sering datang mengisi seminar-seminar umum dibeberapa Perguruan Tinggi dan juga telah mendirikan beberapa lembaga pendidikan bertaraf internasional. Terkait gagasan pendidikan Gulen, KH. Abdurrahman Wahid (Alm) memberikan apresiasi yang amat besar terhadapnya dan menganjurkan supaya pendidikan di Indonesia meniru konsepnya.

Gagasan Gulen: pendidikan berbasis love (etika); ekonomi memanfaatkan dana zakat untuk mendirikan usaha-usaha dan jejaraing ekonomi guna menghidupi pendidikan dan dakwah; dan dialog antara agama dirajut dari pemahaman kebijaksanaan sufi dan interpretasi nash dengan hermeneutika modern.
\end{abstract}

Key words: Gullen, Turki, Pendidikan, Ekonomi, dan Dialog Antar Umat Beragama

\section{Pendahuluan}

Semenjak permulaan abad ke-18, banyak wilayah Muslim menghadapi tantangan hebat akibat dari ekonsomi dan militer pihak

\footnotetext{
* Dosen Mahad Aly Lirboyo Kediri
} 
Fethullah Gulen, Oleh: Aly Mashar

Barat. Melihat kemajuan ilmu pengetahuan dan teknologi di Barat, umat Islam sadar akan ketertinggalannya. Di penghujung abad ke-19 dan awal abad ke-20, mayoritas negara Muslim jatuh atau berada dibawah jajahan kolonial Barat-Eropa. Dengan ini maka keprihatinan yang diderita oleh umat muslim kian berat, kemajuan perekonomian dan pendidikan pun jauh tertinggal, Kemiskinan merajalela dan seterusnya. ${ }^{1}$

Melihat situasi umat Islam yang memprihatinkan ini, beberapa pemikir Muslim dan ulama berusaha untuk bangkit dan membangkitkan umat Islam dari keterpurukannya. Dalam upaya pembangkitan ini, satu tokoh dengan tokoh lainnya mempunyai cara dan pandangan yang berbeda-beda, namun secara garis besar mempunyai tujuan yang sama, yakni membangkitkan umat Islam dan berusaha menyeimbangkan posisi antara 'Islam' dan 'Barat'.

Upaya pembangkitan ini, pada umumnya juga mempunyai pola yang sama, yakni seorang tokoh mengeluarkan gagasan pembaharuan dan pembangkitannya yang kemudian menjalar hingga membentuk suatu gerakan kelompok yang terorganisir, baik itu dibawah pimpinan sendiri tokoh penggagas tersebut maupun dibawah pimpinan orang lain yang terpengaruh oleh gagasan seorang atau lebih tokoh penggagas pembaharuan dan pembangkitan. Untuk sekedar contoh, kelompok yang pertama misalnya gerakan Ikhwanul Muslimin Hasan al-Bana di Mesir, Jemaat Islamiyah Maududi di Pakistan, dan, baru-baru ini, gerakan transnasional Hizbut Tahrir Albani; kelompok yang kedua misalnya Muhammadiyah Ahmad Dahlan di Indonesia yang terpengaruh Muhammad Abduh dan Gerakan Wahhabiyah Ibn Su'ud di Saudi Arabia yang terpengaruh Muhammad bin Abdul Wahhab.

Terlepas dari corak dan jenis gerakan yang berbeda-beda tersebut, yang jelas bahwa sejak permulaan abad ke-18 M, atau bahkan jauh sebelum itu, hingga sekarang gerakan-gerakan yang mengupayakan kebangkitan umat Islam tersebut terus bermunculan. Dari hanya berpusat di Saudi Arabia (Wahabisme), Mesir (Jamaluddin al-Afgahani, Muhammad Abduh, Ikhwan Muslimin Hasan al-Bana), dan Anak Benua India (Syah Waliyullah Dihlawi, Jemaat Islamiyah Maududi), kemudian menyebar ke negara-negara muslim atau yang

${ }^{1}$ John L. Esposito, Islam dan Politik, terj. Joesoef Sou’yb, (Jakarta: Bulan Bintang, 1990), h. 56. 
Fethullah Gulen, Oleh: Aly Mashar

berpenduduk mayoritas muslim di seluruh belahan bumi, termasuk diantaranya adalah Turki. ${ }^{2}$

Sebagaimana kita ketahui bersama, bahwa Turki merupakan pusat peradaban dan pemerintahan Islam terakhir, Dinasti Usmaniyah atau Turki Utsmani. Sebagai pusat pemerintahan, Turki jelas merupakan negara yang mempunyai banyak warisan kekayaan Islam, meskipun sempat dikikis oleh rezim Kemalis selama beberapa tahun, dan juga ditambah lagi dengan letak geografisnya yang merupakan persinggungan antara 'Barat dan Timur', dengan begitu, maka tidak heran jika di negara tersebut banyak muncul pemikir besar. Salah satu pemikir kontemporer terkemuka Turki adalah Fethullah Gulen. Ia merupakan seorang aktifis da'i, reformis, pemikir pendidikan, ekonom, dan juga tokoh penggagas dialog antar agama.

Pengaruh Gulen tidak hanya terasa di Turki, namun hampir ke seluruh negara dunia, termasuk di Indonesia. Bahkan, mantan presiden RI ke-4, KH. Abdurrahman Wahid, memberikan apresiasi yang sangat besar terhadap salah satu gagasannya, yakni gagasan pendidikan yang berbasis 'love' dan mengedepankan etika. Bahkan cucu pendiri Nahdlatul Ulama ini menganjurkan supaya gagasan Gulen ini diterapkan di Indonesia, yang di mana pendidikannya sedang di landa krisis moral.

"Ini sesuatu yang sangat penting apalagi bagi bangsa Indonesia karena sekolah-sekolah kita ini sekarang hampa moral. Kehampaan moral ini telah mengakibatkan terjadinya berbagai pelanggaran yang ada di masyarakat, maraknya korupsi, dan berbagai penyelewengan yang dilakukan birokrasi merupakan salah satu akibatnya. Ini menunjukkan bahwa ada krisis didalam dunia pendidikan kaum Muslimin di Indonesia. Karena itu, saya rasa belajar bagaimana mengembangkan akhlak yang baik dalam pendidikan kita menjadi sangat penting,"3

Dengan dasar di atas, maka gagasan Gulen sekaligus gerakannya penting untuk dikaji. Untuk mempermudah bahasan, penulis

${ }^{2}$ Untuk lebih jelasnya terkait macam-macam dan tokoh-tokoh gerakan pembaharuan muslim, Lih. Esposito, Islam dan Politik..,

${ }^{3}$ Ari, "Fethullah Gulen: Sang Perajut Jejaring dunia Islam", dalam Suara Merdeka, (www.suaramedia.com, diakses tanggal 20 Desember 2010).

Vol. 22 Nomor. 1 Januari 2011 
Fethullah Gulen, Oleh: Aly Mashar

merumuskan fokus bahasan sebagaimana berikut: (1) Bagaimana keterlibatan Fethullah Gulen dengan gerakan islam Turki kontemporer? (2) Bagaimana gagasan-gagasan dan gerakan Fethullah Gulen? Dan, (3) Apa sumbangsih Fethullah Gulen terhadap perkembangan Rakyat Turki, khususnya, dan umat Islam pada umumnya?

\section{Biografi, Pendidikan dan Karya}

Fethullah Gulen lahir di desa kecil, Korucuk, dekat Erzurum, Turki Timur, 27 April 1941. Ia lahir dari keluarga yang berpendidikan, baik sekular maupun keagamaan. Ramiz Gulen, ayahnya, adalah seorang sarjana sekaligus seorang imam masjid yang ditunjuk oleh negara di kotanya. Sedangkan ibunya secara diam-diam berprofesi sebagai pengajar al-Qur'an bagi kaum perempuan di desanya. ${ }^{4}$ Dikatakan secara diam-diam, karena sejak Turki dipimpin Kemal Attaturk (1922), dengan alasan nasionalisme dan sekularisme, pada tahun 1924 seluruh lembaga pendidikan keagamaan di Turki dilarang dan digantikan dengan pendidikan sekular. Pelarangan ini terus berlanjut hingga 1949 (pendidikan keagamaan sebagai pilihan) dan 1950 (pendidikan keagamaan diwajibkan kembali). Jadi, Gulen lahir ketika paham sekularisme Kemalis sudah mulai melunak. ${ }^{5}$

Orangtua Gulen memasukkannya ke dalam sekolah dasar sekular terdekat di kotanya, yakni di lingkungan masjid di mana ayahnya menjadi Imam. Namun, di sekolah dasar sekular ini Gulen hanya sempat mengenyam selama tiga tahun, sekolah dasar pertama. Kondisi ini harus ia terima karena, ketika itu, ayahnya ditunjuk oleh negara untuk menjadi imam di sebuah masjid di kota lain yang tidak ada sekolah dasar keduanya. Karena situasi ini, kemudian Gulen memutuskan untuk tidak meneruskan sekolah formalnya dan mulai mengikuti pengajaran informal ayahnya. Dari ayahnya, Gulen mendapat pengajaran tentang ajaran-ajaran dasar Islam dan beberapa keilmuan Arab dan Persia. Di samping mendapat pengajaran dari ayahnya, ia menghabiskan hari-harinya untuk membaca buku, tadarus al-Quran, bermeditasi kepada nabi Muhammad dan para sahabatnya, dan membaca puisi-puisi keagamaan. ${ }^{6}$

\footnotetext{
${ }^{4}$ M. Hakan Yavuz, Islamic Political Identity in Turkey, (New York: Oxford University Press, 2003), h. 180.

${ }^{5}$ Esposito, Islam dan Politik, h. 133-137.

${ }^{6}$ Helen Rose Ebaugh, The Gulen Movement: A Sociological Analysis of a Civic Movement Rooted in Moderate Islam, (New York: Springer, 2010), h. 23-24
} 
Fethullah Gulen, Oleh: Aly Mashar

Selain hal di atas, Gulen juga diuntungkan dengan banyaknya sarjana, pemikir dan guru spiritual yang datang ke rumahnya untuk menggelar diskusi terkait isu-isu keagamaan dengan ayahnya. Dengan demikian ia pun sering ikut nimbrung di dalamnya, meskipun forum tersebut digelar dan diikuti oleh mereka yang berumur jauh di atasnya. Dikarena sering ikut nimbrung forum ini, Gulen tidak punya waktu untuk berhubungan atau bercengkerama dengan teman-teman sebayanya. Situasi ini sebagaimana penjelasan Gulen yang dikutip oleh Helen Rose E. sebagai berikut:

“...guesthouse for all knowledgeable and spiritually evolved people in the region... Guests, especially scholars, were frequent in our house. We paid great attention to host them. During my childhood and youth, I never sat with my peers or age group; instead, I was always with elder people and listened to them talk about things of mind and heart."

Dari forum diskusi itu, Gulen mendapatkan banyak pelajaran, baik terkait keagamaan, spiritualitas, modernitas, dan penalaran. Dari forum ini pula Gulen diperkenalkan dengan pemikiran dan karya-karya Said Nursi oleh para guru spiritual, terutama Syeikh Muhammad Lutfi Efendi, yang sangat mempengaruhi Gulen. Said Nursi adalah seorang dai sekaligus tokoh sufi modern (non-tarekat) terkemuka yang memperjuangkan agar Islam mampu selaras dengan modernisasi (Barat). Dia menyatakan bahwa agama (Islam) dan ilmu pengetahuan tidaklah bertentangan. Gerakan Nursi ini, yang disebut Nurcu, menyebar luas ke seluruh Turki setelah tahun 1950 dan mendapat pengikut yang sangat luas, terutama sekali para pemuda dan para pelajar di sekolah sekular. Setelah perkenalannya ini, kemudian Gulen sangat aktif mengikuti kajian-kajian yang digelar oleh para pengikut Nursi tersebut. ${ }^{8}$

Selain mempelajari ilmu-ilmu keagamaan (teologi, Fiqih, Tafsir, dan lain-lain) dan pemikiran-pemikiran para pemikir muslim -terutama pemikiran Said Nursi, Jalaludin Rumi, al-Ghazali, dan Yunus Emre- ${ }^{9}$, Gulen juga mempelajari pemikiran-pemikiran sekular (sejarah, filsafat,

\footnotetext{
${ }^{7}$ Ibid., h. 24.

${ }^{8}$ Bulent Aras dan Omer Caha, "Fethullah Gulen and His Liberal 'Turkish Islam' Movement”, dalam Middle East Review of International Affairs, Vol. 4. No. 4, Desember 2000.

${ }^{9}$ Greg Barton, "Progressive Islamic Thought, Civil Society and The Gulen Muvement in The National Context: Paralells with indonesia", dalam (http://www.fgulen.org/conference-papers/, diakses tanggal 18 Desember 2010).
}

Vol. 22 Nomor. 1 Januari 2011 
Fethullah Gulen, Oleh: Aly Mashar

sastra, dan sains) dari para pemikir Barat, seperti Camus, Sartre, Marcuse (eksistensialis), Rousseau, Balzac, Dostoyevski, Pushkin, Darwin, Tolstoy, ${ }^{10}$ dan terutama sekali Imanuel Kant. Terkait tokoh yang terakhir ini, ia sangat kagum dan memberikan apreasi yang sangat besar terhadap pemikirannya. ${ }^{11}$

Karena tidak mempunyai ijazah sekolah dasar kedua, Gulen berusaha mencari dan berhasil mendapatkannya melalui ujian eksternal. Setelah mendapatkannya, pada tahun 1959 dia mengikuti ujian negara untuk menjadi imam dan akhirnya lulus, diterima. Karena hasil ujiannya sangat mengagumkan, ia ditugaskan oleh negara untuk menjabat sebagai petinggi bagi imam-imam yang lainnya di kota kelahirannya, Erzurum. Jadi, dilihat dari tahun kelahiran dan tahun pengangkatan sebagai imam, Gulen sudah menjadi imam ketika ia masih berusia 18 tahun. $^{12}$

Di tempat barunya ini, Gulen mulai memperkenalkan gagasangagasannya, baik terkait pendidikan, sains, ekonomi, maupun keadilan sosial. Ia juga memimpin asosiasi orang-orang Turki (Turkish Association) untuk berjuang melawan Komunisme Erzurum, dan di kemudian hari ia merekrut penyokong ideologis untuk melawan bahaya politik Islam Iranian. Dengan demikian, bisa dikatakan bahwa di kota ini Gulen sudah memperlihatkan pendiriannya tentang politik kenegaraan, yakni Islam-Nasionalis, bukan Islam-Formalis maupun Komunis-Sosialis. ${ }^{13}$ Dan terlihat pula, bahwa di sini dia juga sudah mulai membangun basis pengikutnya, yang mayoritas adalah para siswa sekolah menengah dan perguruan tinggi.

Pengaruh Gulen kian hari kian meluas. Ia tidak hanya memberi ceramah dan mengajar di Erzurum, namun juga di hampir seluruh masjid atau sekolah di Turki. Hal ini bukan berdasarkan permintaan Gulen sendiri, namun karena diundang oleh mereka. Jadi bisa disimpulkan bahwa rakyat Turki banyak yang merespon atau mengapresiasi apa yang diperjuangkan Gulen. Bahkan, para pejabat kota pun juga nampak memberikan apresiasi terhadapnya, sebab mereka

\footnotetext{
${ }^{10}$ Eyup Can, “A Tour of Horizon with Fethullah Gulen (Fethullah Gulen Ille ufuk Turu)", dalam Zaman, Agustus, 1995.

${ }^{11}$ Bulent, "Fethullah Gulen and His Liberal..."

${ }^{12}$ Ebaugh, The Gulen Movement ..., h. 26.

13 Ibid.,
} 
Fethullah Gulen, Oleh: Aly Mashar

juga sering mengundang Gulen di pertemuan-pertemuan formal dan informal mereka. ${ }^{14}$

Selain melalui Ceramah, gagasan-gagasan Gulen juga ia gaungkan dan tularkan melalui tulisan, baik berbentuk artikel, jurnal maupun buku. Tulisan Gulen tidak kurang dari 60 buah dalam pelbagai bentuk dan topik bahasan. Yang sangat menonjol diantaranya ialah mengenai pendidikan, hubungan antar umat beragama, dan sufi. ${ }^{15}$

Meski umur sudah mulai senja, hingga saat ini Gulen terus menebarkan gagasan-gagasannya. Bahkan tidak hanya di lingkup Turki, namun ke pelbagai negara dunia, termasuk di dalamnya Malaysia dan Indonesia. ${ }^{16}$

Perlu diketahui, Gulen juga pernah ditangkap serta dijelbloskan ke penjara selama 6 bulan. Hal ini terjadi pada awal tahun 1971 dengan tuduhan bahwa gerakan yang dipimpinnya tersebut secara periodik membahayakan otoritas pemerintah. Kemudian pada tahun 2000, dia didakwa kembali dengan tuduhan telah merencanakan kudeta dan ingin mengganti pemerintahan Turki yang sekular dengan pemerintahan Islam. Namun tuduhan tersebut tidak terbukti dan pada tahun 2006 dia dinyatakan bebas dari segala tuduhan.

\section{Latar Belakang Gagasan dan Gerakan Gulen}

Sebagaimana telah diinsyafi bersama bahwa setiap teori atau gagasan tidak akan lahir dalam ruang kosong. Dalam arti pasti ada historisitas atau latarbelakang yang menjadikan gagasan tersebut muncul. Hal ini juga terjadi pada gagasan dan gerakan Gulen. Ia membangun gagasan, yang kemudian mewujud pada suatu gerakan, berdasarkan pada realitas sosial-politik yang ia hadapi, dan pastinya

\footnotetext{
${ }^{14}$ Ari, "Fethullah Gulen: Sang Perajut Jejaring dunia Islam", dalam Suara Merdeka, (www.suaramedia.com, diakses tanggal 20 Desember 2010)

15 Diantara karyanya ialah (bahasa Turki) Cag ve Nesil, 1982; Asrin Getirdigi Tereddutler, 1983; Renkler Kusaginda Hakikat Tomurcuklari, 1985; Olum Otesi Hayat, 1987; Yitirilmis Cennete Dogru, 1988; (bahasa Inggris) Toward the Lost Paradise, 1996; Pearls of Wisdom, 1997; Key Concepts in the Practice of Sufism Vol1, 1998; The Essentials of the Islamic Faith, 2000; Questions and Answers about Islam Vol 1, 1993 dan 2000; The Necessity of Interfaith Dialogue, 2004; Islamic and Democracy, 2004; Key Concepts in the Practice of Sufism Vol-2, 2004; Toward a Global Civilization of Love and Tolerance, 2004; Religious Educations of the Child, 2004; dan masih banyak lagi.

${ }^{16}$ Apristia K. Dewi, "Model Pendidikan Fethullah Gulen Layak Diapresiasi”, dalam UIN Online, (http://www.uinjkt.ac.id/, diakses tanggal 23 Desember 2010).
}

Vol. 22 Nomor. 1 Januari 2011 
Fethullah Gulen, Oleh: Aly Mashar

juga dipengaruhi oleh faktor internal Gulen, yakni faham keagamaan dan keilmuannya. Di bawah ini akan disinggung sekilas latar-latar tersebut.

\section{Situasi Politik}

Secara garis besar, situasi sosial-politik Turki, di era Gulen hidup, adalah bahwa tampuk pemerintahan Turki sudah tidak lagi dipegang oleh para Kemalis yang memperjuangkan Sekularisasi yang sangat ketat, bahkan hingga sekolah-sekolah keagamaan, tarekat-tarekat sufi, dan kegiatan-kegiatan keagamaan lainnya dihapus dan dilarang. ${ }^{17}$ Ketika itu, pasca diterapkannya politik demokrasi multi-partai (1946), tampuk kekuasaan beralih ke tangan Partai Demokrat, salah satu rival partai RPP-Kemalis. ${ }^{18}$

Untuk melanggengkan kekuasaannya pada pemilu periode selanjutnya (1950), Partai Demokrat berusaha mengambil hati para kelompok agama dengan cara melonggarkan politik sekular negara. Pada tahun 1949, Partai Demokrat mengizinkan mata pelajaran keagamaan diajarkan di sekolah-sekolah dan mewajibkannya pada tahun 1950. Dan juga, pada tahun ini, Fakultas Teologi di Universitas Ankara yang berguna untuk mendidik para imam dibentuk kembali. Dengan usahanya ini, Partai Demokrat berhasil menggaet hati kelompok agama, terutama kelompok agama "the Followers of Light" yang dipimpim oleh Said Nursi. ${ }^{19}$

Sejak itu, tepatnya sejak diberlakukannya sistem multi-partai dan dilonggarkannya politik sekular negara oleh Partai Demokrat, gerakangerakan keagamaan dan partai-partai politik yang berbasis keagamaan merebak muncul bak jamur di musim hujan. Gerakan-gerakan keagamaan diantaranya ialah gerakan tarekat Naqshabandiyah yang kemudian mengilhami gerakan keagamaan Fethullahci dan gerakan Nurcu -nama lain dari gerakan Said Nursi- yang di kemudian hari menginspirasi gerakan Fethullah Gulen; ${ }^{20}$ sedangkan partai politik berbasis agama diantaranya ialah: Nation Party, berdiri tahun 1948 dan

${ }^{17}$ Untuk lebih jelasnya tentang sekularasisai Kemalis ini, lih. Marshall G. S. Hodgson, The Venture of Islam: Conscience and History in a World Civilization, The Gunpowder Empires and Modern Times, Vol-3, (Chicago and London: The University of chicago Press, 1974), h. 262-271, dan Esposito, Islam dan Politik ..., h. 133-135.

${ }^{18}$ Esposito, Islam dan Politik, h. 137

19 Ibid., 137-138.

${ }^{20}$ John L. Esposito, Ancaman Islam: Mitos atau Realiti?, terj. Nor Azita Omar, (Kuala Lumpur: Institut Terjemahan Negara Malaysia Berhad, 2004), h. 109.

Vol. 22 Nomor. 1 Januari 2011 
Fethullah Gulen, Oleh: Aly Mashar

dibubarkan negara tahun 1953 karena dianggap menggunakan agama dalam politik yang merupakan larangan negara, namun belakangan didirikan kembali dengan berganti nama Republican Nasion Party; Party of Union, didirikan tahun 1966 oleh kaum Syi'ah Imam Dua belas sekte Alawiyah, partai ini kemudian menggaet kaum minoritas lainnya di Turki, termasuk kaum kiri; dan National Order Party, didirikan tahun 1970 oleh kaum Sunni yang dipimpin oleh Necmeddin Erbakan. Karena dituduh anti-sekular, beberapa tahun kemudian partai ini dibubarkan negara, namun tak lama kemudian, 1972, didirikan kembali dengan nama National Salvation Party dan kemudian Welfare Party (Partai Kesejahteraan). ${ }^{21}$

Singkatnya, pada tahun-tahun ini perpolitikan Turki dipenuhi oleh aliran politik ekstrim, yang mendorong negara ke arah anarki. Separatisme kesukuan, tindakan-tindakan teror-baik dari sekular radikal maupun Islam fundamental-, dan pertentangan sekte keagamaan -Sunny-Syi'ah Alawiyah, meningkat drastis. Ketegangan antar sekte dan antar agama ini diperparah lagi dengan berhasinya Revolusi Ayatullah Khomeini di Iran pada tahun 1979. Demonstrasi-demonstrasi menuntut dibentuknya Negara Islam, terutama dari NSP Ebarkan, kian menjamur dan menguat. Namun, situasi ini meredam setelah junta Militer pengikut Kemalis merebut kekuasaan pada bulan September 1980. Mereka menumpas unsur-unsur 'radikal' dan menjebloskan Ebarkan ke penjara. ${ }^{22}$ Meskipun pemimpinnya dijebloskan ke penjara, aktivitas politik partai Ebarkan, NSP, terus berlanjut. Ia masih bisa mengikuti pemilu, bahkan hingga sekarang. ${ }^{23}$

Dalam situasi politik seperti ini, sejak dia diangkat menjadi Imam atau da'i oleh negara, Gulen memilih untuk tidak ikut aktif di dalamnya. Hal ini bukan berarti ia tidak mempunyai pandangan politik dan mempunyai kedekatan dengan salah satu partai pemain. Gulen menentang politik Islam-Formalis sebagaimana dibuktikan bahwa ia mengkonter NSP, dan tidak mendukung Sekular an sich, meskipun ia nampak dekat dengan kelompok yang terakhir. Pandangan politik Gulen ialah Islam-Nasionalis, Islam yang dijiwakan atau disublimasikan dengan nasionalis Turki. ${ }^{24}$ Ia juga mempunyai kedekatan dengan Ozal, Perdana Menteri Turki Kemalis. Bahkan Gulen membantu

\footnotetext{
${ }^{21}$ Esposito, Islam dan Politik, h. 139

${ }^{22}$ Ibid., h. 139-140.

${ }^{23}$ Yavuz, Islamic Political Identity...,198.

${ }^{24}$ Esposito, Ancaman Islam ..., 107.
}

Vol. 22 Nomor. 1 Januari 2011 
Fethullah Gulen, Oleh: Aly Mashar

berkampanye, meskipun tidak masuk partai Kemalis, untuk menghalau suara NSP pada pemilu 1991, 1995, dan 1999; dan mendukung kebijakan politik ekonomi Neo-Liberal yang dicanangkan Ozal. Kedekatannya dengan Ozal ini ia nyatakan sendiri sebagai berikut;

"I had a close relationship with Turgut Ozal when he was working on the State Planning Organization. He regularly visited my house and we had breakfast and dinner together on many occasions. He even attended my mosque and listened to my sermons. We held many conversations about social and political developments in Turkey. Just a week before the September 12 military takeover, he visited me and asked what I was thinking about the prevailing anarchy and chaos. I told him that as far as the future of Muslims was concerned, "I am positive". He responded, "[The] political situation is getting worse.

Dari sini maka bisa disimpulkan bahwa Gulen dan Gerakannya tidak terikat dengan partai politik manapun, meskipun ia dekat dengan partai atau pihak Kemalis. Ia lebih memilih model gerakan kultural daripada politik-struktural, meskipun ia juga nampak menggunakan peluang 'kemudahan gerak' yang diberikan oleh Ozal. Dan juga bisa dipahami bahwa, di Turki, terjadi pertentangan yang hebat antara dua sisi ekstrim, baik dalam wacana politik (Sekular Kemalis dan Islam Fundamental Ebarkan) maupun antar suku, agama dan sekte keagamaan (Sunny-Syi'i Alawiyah). Di sini maka terlihat bahwa sikap Gulen mengambil sisi tengah (moderat) antara kedua titik ekstrim (politik). Dan situasi ini kiranya yang memberikan inspirasi terhadapnya untuk menggagas 'Dialog Antar Umat Beragama', di samping pengaruh dari ajaran sufistik (harmoni) yang ia geluti.

\section{Situasi Sosial [Ekonomi] dan [Faham] Keagamaan}

Sejak dimulainya proyek sekularisasi oleh Kemal at-Taturk tahun 1922-23, keadaan perekonomian Turki kian hari kian bergantung dengan Amerika. Tahun 1960 sampai 1980, industri pengganti barang impor yang amat diproteksi mulai dibangun, dan kaum kapitalis serta serikat-serikat dagang menduduki posisi penting. Pada tahun 1980 dan seterusnya, pemerintahan Ozal menggandeng IMF, Bank Dunia dan OECD untuk membalik sistem perekonomian pemerintahan pra-1980, yakni memperkuat Ekspor dan menekan impor. Akibat dari kebijakan

${ }^{25}$ Yavuz, Islamic Political Identity..., 198.

Vol. 22 Nomor. 1 Januari 2011 
Fethullah Gulen, Oleh: Aly Mashar

ini, tahun 1980, Turki mempunyai hutang sebesar $\$ 13,5$ miliar, tahun 1989 sebesar \$40 miliar dan tahun 1994 meningkat lagi menjadi \$70 miliar. Diawal kebijakan ini, perekonomian Turki menggeliat menguat, namun tidak begitu dengan tahun 1994, Turki mengalami krisis yang hebat. $^{26}$

Proyek tersebut dilanjutkan oleh Ciller. Untuk mengentaskan Turki dari jeratan krisis, Ciller mengeluarkan kebijakan untuk privatisasi aset-aset negara (1994), namun tidak banyak aset negara yang laku di pasaran. Hal ini karena perusahaan negara sangat gemuk dalam keorganisasiannya, sehingga para investor kurang minat terhadapnya. Meskipun demikian, keadaan perekonomian Turki mulai menguat kemblai, tapi, karena beberapa kekeliruan pengelolaan, tahun 1996 terpuruk kembali. Segera setelah Erbakan berkuasa, sebelumnya pemerintahan dipegang oleh Damirel-Inonu (koalisis Ciller) yang tidak banyak merubah kebijakan ekonomi, kebijakan-kebijakan Ciller dihapus. Ia juga mengumumkan kenaikan gaji pegawai pemerintah sebanyak $50 \%$ bagi 1,8 juta pegawai dan gaji pensiunan hingga kenaikan $130 \%$. Hal ini, menurut pengakuan Erbakan, diambil dari dana hasil pendapatan estra privatisasi, penghapusan pasar gelap, dan dari penjualan tanah negara. ${ }^{27}$

Dari kebijakan politik ekonomi yang semakin lama semakin liberal di atas, menjadikan jurang pemisah antara si miskin dan si kaya semakin menganga jauh. Perhatian pemerintah hanya terpusat pada para pengusaha, importir, eksportir, dan konstruktor yang tidak lain ialah hanya segelintir orang. Nasib rakyat kebanyakan, seperti para petani dan pekerja [buruh] sangat minim diperhatikan, bahkan tidak sedikit masyarakat yang menganggur. Dengan demikian, di Turki, di samping muncul beberapa gelintir orang yang kaya raya, kemiskinan pun merajalela. $^{28}$

Sebagaimana lazimnya di negara yang dilanda ketidaksetabilan ekonomi dan banyaknya kemiskinan, ketidakpuasan dari pelbagai kalangan rakyat jelata atas kerja pemerintah pun ikut menyeruak muncul. Apalagi, Turki termasuk negara yang rakyatnya multi etnis dan sekte keagamaan. Karena ketidakpuasan ini didukung oleh ideologi, suku/ etnis, dan sekte yang mempunyai pandangan yang berbeda-beda,

${ }^{26}$ Erikj. Zurcher, Sejarah Modern Turki, terj. Karsidi D.R, (Jakarta: PT. Gramedia, 2003), 400-402.

${ }^{27}$ Ibid., 412-413.

${ }^{28}$ Ibid, 408-409.

Vol. 22 Nomor. 1 Januari 2011 
Fethullah Gulen, Oleh: Aly Mashar

maka 'bentrokan' pun tak bisa dihindari. Dengan kata lain, dengan adanya krisis ekonomi tersebut, pertentangan-pertentangan antar entis, sekte, ideologi, dan bahkan agama pun menguat hebat. Situasi sosial menjadi kacau. ${ }^{29}$ Berdasarkan pada situasi inilah Gulen mencetuskan gagasan pendidikannya. Menurutnya, munculnya kemiskinan dan problematika ekonomi yang sangat akut tersebut dikarenakan oleh lemahnya pendidikan masyarakat. Oleh karena itu, untuk meningkatkan taraf kehidupan masyarakat tersebut tidak ada jalan lain yang sangat urgen dibanding dengan peningkatan pendidikan. ${ }^{30}$

\section{Pemahaman Keagamaan Gulen}

Sebagaimana disinggung di awal pembahasan ini, bahwa Gulen sangat dipengaruhi oleh gerakan progressif-modernis nurcu Said Nursi dan juga faham sufistik cinta, terutama Jalaludin Rumi. Dan perlu diketahui bahwa Gulen adalah penganut sekte mayoritas di Turki, yakni Sunni Hanafi (fiqih) dan Maturidi (Teologi) yang menghormati rasionalitas dan moderatisisme. Dari sini bisa dikatakan bahwa Gulen adalah salah satu pemikir kontemporer yang mengangkat kembali atau melakukan re-interpretasi 'pengetahuan klasik' ke era modern. Hal ini sebagaimana dinyatakan oleh Philipp Bruckmayr sebagai berikut:

"From the foregoing it becomes evident, that Gülen indeed displays a remarkable breadth of scholarship encompassing all fields of Islamic knowledge from earliest up to modern times ...In many ways he shows himself to be both a devoted adherent of Islamic mysticism and its ideals as well as a highly traditional Turkish Sunni scholar. This includes his explicit reliance on the Hanafi school of law (and especially its Central Asian figures such as al-Sarakhsi), his nominal preference for Maturidi kalam...,31

Dari ketiga corak hal yang mempengaruhi Gulen di atas dan juga sikapnya atas 'pengetahuan klasik' dan 'modernitas', maka bisa ditarik kesimpulan bahwa pemahan keagamaan Gulen mengambil pemahaman 'moderatisisme'. Dalam artian, dia tidak melupakan 'yang lalu' dan tidak menolak 'hal baru' yang lebih baik; Tidak melupakan kebenaran agama dan tidak menolak kebenaran pengetahun; Tidak 'arabisme' dan

\footnotetext{
${ }^{29}$ Ibid,.

${ }^{30}$ Ari, "Fethullah Gulen ..",

31 Philipp Bruckmayr, "Fethullah Gulen and Islamic Literary Tradition", dalam Islamic in the Age of Global Challenges-Conference Proceedings.
} 
Fethullah Gulen, Oleh: Aly Mashar

tidak pula 'sekularisme'; tidak mengalahkan 'rasio' atas 'nash'; dan seterusnya. Kemudian, dari sufisme cinta Rumian, Gulen menjadi manusia yang 'cinta' akan semuanya, baik berbeda suku, sekte, atau bahkan agama. Singkatnya, dari sufisme ini Gulen menjadi manusia yang sangat menyukai 'keharmonisan', menghargai pluralitas dan seterusnya. Sampai di sini, keterangan tentang faham keagamaan Gulen sudah kami anggap cukup untuk mengantarkan pada pembahasan selanjutnya. Sebab, paper ini tidak dimaksudkan untuk membahas hal ini. $^{32}$

\section{Gagasan dan Gerakan Fethullah Gulen}

Dalam kajian ini, antara gagasan dan gerakan Gulen akan peneliti kaji dalam satu bab bersama-sama, sebab keduanya saling berkait kelindan. Dan karena alasan waktu dan halaman, di sini peneliti hanya akan memfokuskan pada tiga gagasan dan gerakan Gulen, yakni terkait Pendidikan, Ekonomi, dan Dialog antar Agama.

\section{Pendididkan}

Pendidikan yang digagas oleh Gulen dan gerakannya adalah pendidikan yang menekankan pada pendidikan etika, sains (ilmu-ilmu sekular dan juga teknologi) dan ilmu-ilmu keagamaan. Bagi Gulen, etika adalah hal yang sangat penting dalam pendidikan, sebab ia adalah hal yang akan membimbing sains dan bahkan ilmu keagamaan. Bahkan Gulen menyatakan bahwa kegagalan pendidikan di eranya dalam mencetak generasi yang ideal adalah karena pendidikan tersebut telah membelokkan siswa dari nilai-nilai kemanusiaan atau etika. Misalkan, dalam mempelajari sains siswa juga harus diajarkan rasa tanggungjawab atas akibat-akibat yang dihasilkan sains tersebut, seperti polusi udara dan lain-lain. ${ }^{33}$

Yang dimaksud 'etika' oleh Gulen ialah 'love'. Dengan cinta, siswa akan mampu merekonsiliasi antara sains dan kepentingan alam dan manusia; dan dengan cinta pula siswa akan patuh secara absolut

${ }^{32}$ Untuk lebih jelas terkait faham keagamaan Gulen, bisa dilihat dibeberapa karyanya atau di Erol Nazim Gulay, "The Theological Thought of Fethullah Gulen: Reconciling Science and Islam", dalam tesis For the Degree of M.Phil in Oriental Studies/ Modern Middle Eastern Studies in St. Antony's College Oxford University, 2007.

${ }^{33}$ Charles Nelson, "Fethullah Gulen: A Vision of Transcendent Education", dalam (www.gulenconference.net, diakses tanggal 29 Desember 2010).

Vol. 22 Nomor. 1 Januari 2011 
Fethullah Gulen, Oleh: Aly Mashar

kepada Tuhan dan mampu berbuat baik kepada atau mengorbankan kepentingan individunya untuk kepentingan masyarakat umum.

"That reconciliation, Gülen asserts throughout his writings, requires knowledge and love. Knowledge is the province of the sciences and provides students with the intellectual abilities to benefit others. Alone, however, the sciences are insufficient in leading people to benefit others. Love is needed"34

"By love, Gülen means self-sacrificing love that initiates action by absolute obedience to God and out of concern for others rather than individual reward or utilitarian calculations for one's happiness ... This love entails selfsacrifice, abnegation, and the personal conviction to transform life on earth"35

Konsekuensi dari hal di atas, ter-integrasi-nya cinta dengan sainstek, maka tidak semua guru adalah pendidik. Menurut Gulen, "Education is gifferent from teaching. Most people can teach, but only a very few can educated". 36 Mengajar adalah hanya semata-mata menyampaikan pengetahuan, sedangkan mendidik selain menyampaikan pengetahuan juga menanamkan cinta berkorban (sacrificial love) dan membimbing moralitas.

Guru, selain hal di atas, juga merupakan pembentuk karakter siswa. Oleh karena itu guru juga harus memberi teladan atas mereka. Sebab, menurut Gulen, untuk mentransfer karakter orang lain, seseorang [guru] harus mentransfer karakter dirinya sendiri terlebih dahulu. Gulen mensyarat bagi guru dua hal, pertama ia harus mencintai dan perhatian terhadap siswa dan, kedua, harus mengembangkan karakter dirinya sebanyak mungkin, setidaknya melebihi karakter siswanya. ${ }^{37}$

Menurut hasil wawancara dengan salah satu guru salah satu sekolah didikan Gulen, Ozdalga menemukan beberapa nilai tertentu, selain cinta, yang diajarkan, yakni pietisme, kemanusiaan, self-criticism, aktivisme kemasyarakatan, profesionalisme, dan sikap toleransi. ${ }^{38}$

34 Ibid.

${ }^{35}$ Yavuz, Islamic Political Identity ..., h. 34.

${ }^{36}$ Fethullah gulen, Toward a Global Civilization of Love and tolerance, (Somerset: The light, 2004), 208.

${ }^{37}$ Nelson, "Fethullah Gulen: A Vision.."

${ }^{38}$ Ibid., 
Fethullah Gulen, Oleh: Aly Mashar

Terkait hubungan antara Agama [Qur'an] dan sains-tek, menurut Gulen keduanya tidak ada pertentangan. Agama [Qur'an] mendukung atau menganjurkan manusia untuk mempelajari sains-tek. Bagi gulen, al-Qur'an memerintah manusia untuk mencari 'kebenaran', dan pada realitanya kebenaran eksis secara independent dari manusia. Dengan kata lain 'kebenaran' tidak akan didapatkan kecuali manusia mau mencarinya. ${ }^{39}$

Selain hal-hal di atas, menurut Gulen pendidikan tidak hanya di dominasi oleh hal-hal teoritis saja, namun harus diaplikasikan menjadi sebuah 'aksi'. Aksi merupakan elemen yang sangat diperlukan untuk kehidupan. Aksi yang dimaksud Gulen ialah sebuah kerja keras secara konstan untuk mencapai tujuan-tujuan orang tersebut dakan melayani yang lain, dan juga, secara esensial, untuk menjaga identitas seseorang bebas dari pengaruh yang lain. ${ }^{40}$ Namun, aksi harus dibimbing oleh refleksi, yakni melihat dan mengevaluasi ulang semua pandangan yang ditentukan. Melalui refleksi, menurut Gulen seseorang akan mampu menentukan tujuan-tujuannya dengan jelas. ${ }^{41}$

Terkait sarana-prasarana, lembaga-lembaga pendidikan yang didirikan Gulen sangat lengkap dan up to date, seperti laboratorium komputer, sains, bahasa dan lain-lain. Singkatnya, kualitas pendidikan gagasan Gulen tersebut berkualitas excellent. ${ }^{42}$

Model pendidikan Gulen ini dalam waktu singkat merebak di Turki, baik berbentuk perpondokan, SLTA dan universittas. Setidaknya sekarang sudah berjumlah 60 Perpondokan, 200 sekolah tingkat SLTA, dan 7 Universitas. Selain itu, ia bersama para pengikutnya sangat aktif dalam sekolah-sekolah persiapan universitas sebanyak 79 buah, dan juga aktif mengontrol 50 SLTA Swasta di Turki. ${ }^{43}$ Menurut keterangan lain, selain sekolah yang didirikan oleh Gulen dan kelompoknya tersebut, sangat banyak lembaga pendidikan yang meniru model pendidikannya, bahkan tidak hanya di Turki, namun hampir di 90

39 Osman Bakar, "Gulen on Religion and Science: A Theologian's Perspective", dalam (www.gulenconference.net, diakses tanggal 29 Desember 2010).

${ }^{40}$ Fethullah Gulen, Towards the Lost Paradise, (London: Truestar, 1996), h. 85

${ }^{42}$ Yavuz, Islamic Political Identity ..., h. 93.

${ }^{43}$ Ibid.,

Vol. 22 Nomor. 1 Januari 2011 
Fethullah Gulen, Oleh: Aly Mashar

negara dunia. Menurut keterangan terakhir, jumlah lembaga pendidikan yang mengikuti model Gulen sebanyak 500 Institusi. $^{44}$

Selain mendirikan perpondokan, sekolahan, dan universitas, proyek pendidikan gulen juga mendirikan penerbitan sekaligus penerbitan buku, membiayai [usat tutorial, dan memberikan bantuan keuangan, termasuk di dalamnya beasiswa. ${ }^{45}$

\section{Ekonomi}

Proyek pendidikan Gulen dan kelompoknya adalah pendidikan yang menggabungkan antara pendidikan dan perniagaan. Dalam artian, selain menggagas proyek pendidikan, ia juga menggagas bagaimana menghidupi pendidikan tersebut, yakni ekonomi.

Model perekonomian gerakan Gulen sama dengan yang diterapkan oleh gerakan nurcu, yakni memanfaatkan zakat. Bagi kedua gerakan ini, zakat, bila dikelola dengan baik secara berjamaah, hasilnya akan sangat berguna, tidak hanya dapat digunakan untuk meningkatkan taraf perekonomian, namun juga taraf pendidikan masyarakat. Dari sini, kemudian gerakan Gulen mampu mendirikan penerbitan sekaligus percetakan buku, stasiun Televisi, dan juga surat kabar zaman. Dan juga mendirikan bank, ansuransi, serta kedai-kedai. Selain itu, kelompok Gulen ini juga merajut perniagaan baik di dalam atau di luar Turki, termasuk dengan PASIAD. ${ }^{46}$ Menurut salah satu keterangan, pada tahun 1999 aset lembaga Gulen diperkirakan mencapai 25 miliar dolar AS. ${ }^{47}$ Dari usaha perniagaan inilah Gulen dan kelompoknya mampu membiayai proyek pendidikan mereka.

\section{Dialog Antar Agama}

Pemikiran tentang dialog antar agama Gulen tidaklah original dari pemikirannya sendiri, namun lebih pada mencuatkan kembali pemikiran Said Nursi. Pemikiran ini didapatkan dari kombinasi kebijaksanaan sufism dan penafsiran nash menggunakan hermenutika ala filosof dan teolog Barat. Tulisan Gulen yang membahas tentang dialog antar agama ini diantaranya artikel The Necessity of Interfaith Dialogue (penulis tidak mendapatkan file-nya) dan buku Toward a Global Civilization of Love and Tolerance (penulis mendapatkannya).

\footnotetext{
${ }^{44}$ Dewi, "Model Pendidikan Fethullah..."

${ }^{45}$ Esposito, Ancaman Islam..., h. 109.

${ }^{46}$ Ibid.,

${ }^{47}$ Dewi, "Model Pendidikan Fethullah..."
} 
Fethullah Gulen, Oleh: Aly Mashar

Bagi Gulen, dialog antar keimanan [agama] dewasa ini merupakan hal yang sangat penting, terutama untuk menghalau terjadinya clash civilization or interfait, dan hal itu diperintahkan atau terdapat dasarnya dalam nash baik al-Qur'an maupun al-hadis, seperti ayat al-Qur'an 3:64 dan $1: 5^{48}$

Selain dari dua dasar tersebut, Gulen juga merujuk pada sejarah kehidupan nabi dan para sahabatnya. Bahkan, menurut Gulen, Jihad dimasa nabi juga mengandung nilai toleransi, sebab umat muslim dilarang untuk membunuh anak-anak, perempuan, lansia, dan merusak tanam-tanam. ${ }^{49}$ Rujukan atas sejarah kehidupan nabi dan para sahabat ini sangat kuat dipengaruhi oleh kesukaan Gulen untuk meditasi terhadap mereka ketika disela-sela waktu belajar bersama ayahnya semasa kecil.

Menurut Gulen, ada empat hal atau alasan yang membuat umat muslim sulit untuk berdialog dengan agama lain, yakni: (1) banyak umat muslim yang dibunuh oleh orang Kristen terutama sekali di abad yang lalu; (2) curiga bahwa dialog masih terkonttaminasi dengan nafsu misionaris;(3) curiga berbau politis; dan (4) alasan teologis: distorsi citra islam sebagai agama yang mundur dan nabi muhammad sebagai penipu.

Supaya tujuan dialog ini tercapai, menurutnya, langkah pertama yang perlu dilakukan ialah melupakan masa lalu -yang pada realitanya antara agama abrahamik sering terjadi peperangan dan klaim saling menyalahkan-, mengabaikan argumen-argumen yang polemik, dan mendahulukan poin-poin umum, yang jauh dari polemik. ${ }^{50}$

Upaya dialog antar agama ini Gulen nampak menuai hasil. Di Turki, atmosfer hubungan antara populasi muslim dan populasi pelbagai agama minoritas seperti Yunani Ortodoks, Armenia Ortodoks, Katolik, dan Yahudi terlihat sangat positif. Di luar Turki, ide dialog ini telah memberikan inspirasi kepada banyak kalangan untuk mendirikan oraganisasi-organisasi dialog. Meskipun dengan nama berbeda, namun tujuannya sama, yakni membentuk atmosfer kehidupan yang harmonispositif antar umat beragama. Upaya Gulen ini juga diakui oleh para

${ }^{48}$ Gulen, Toward a Global Civilization..., h. 257.
${ }^{49}$ Ibid., 180.
${ }_{50}$ Valkenberg, “Fethullah Gulen's Contribution to Muslim-Christian Dialogue in the Context of Abrahamic Cooperation, dalam (www.gulenconference.net,
diakses tanggal 29 Desember 2010).

Vol. 22 Nomor. 1 Januari 2011 
Fethullah Gulen, Oleh: Aly Mashar

petingga agama, termasuk ketua Rabbi Sephardic Israel dan Paus John Paul II, dan Gulen pernah bertemu dengan keduanya. ${ }^{51}$

Demikianlah gagasan dan gerakan Gulen. Manfaat dan pengaruhnya tidak hanya di wilayah negara Turki, namun hampir ke seluruh negara dunia. Dan, dari kajian atas gagasan-gerakan dan yang melatari kemunculannya ini, nampak cocok jika diterapkan di negara kita, Indonesia. Sebab, Turki dan Indonesia sedikit banyak mempunyai keserupaan problem dan ciri diri, yakni masyarakatnya majmuk dan sedang mengalami goncangan ekonomi dan bobroknya sistem pendidikan.

\section{Penutup}

Dari kajian di atas maka bisa disimpulkan bahwa: Gulen sangat aktif dalam membentuk masyarakat Turki menjadi masyarakat yang melek pengetahuan, baik pengetahuan sains-tek dan keagamaan, dan berekonomi mapan. Hal ini ia lakukan dengan menggagas model pendidikan dan juga ekonomi. Selain itu, Gulen juga berupaya untuk membangun hubungan yang harmonis antar populasi agama di Turki. Hal yang terakhir ini ia upayakan dengan menyerukan dialog antar keimanan [agama].

Pemikiran dan gerakan Gulen sangat dipengaruhi oleh gerakan nurcu Said Nursi, ajaran sufisme terutama Jalaludin Rumi, dan ajaran sunni-Hanafiah-Maturidiyah. Selain itu, ia juga dipengaruhi oleh keadaan perekonomian dan pendidikan masyarakat Turki yang memprihatinkan.

Sikap politik, pemikiran, dan gerakan Gulen bisa disimpulkan mengambil posisi moderat. Dan ia, meskipun dekat dengan pihak pemerintah, namun ia tidak terjun langsung ke politik praktis. Gerakannya musni gerakan sosial-kemasyarakatan.

Keberhasilan gagasan dan gerakan Gulen tidak hanya bisa dirasakan oleh rakyat Turki saja, namun juga rakyat, tanpa melihat etnis dan agamanya, di pelbagai negara dunia, termasuk Indonesia.

${ }^{51}$ Fgulen.com, "Introducing Fethullah Gulen..." 
Fethullah Gulen, Oleh: Aly Mashar

\section{Daftar Pustaka}

Aras, Bulent dan Omer Caha, "Fethullah Gulen and His Liberal 'Turkish Islam' Movement', dalam Middle East Review of International Affairs, Vol. 4. No. 4, Desember 2000.

Ari, "Fethullah Gulen: Sang Perajut Jejaring dunia Islam", dalam Suara Merdeka, (www.suaramedia.com, diakses tanggal 20 Desember 2010)

Bakar, Osman, "Gulen on Religion and Science: A Theologian's Perspective", dalam (www.gulenconference.net, diakses tanggal 29 Desember 2010).

Barton, Greg, "Progressive Islamic Thought, Civil Society and The Gulen Muvement in The National Context: Paralells with indonesia", dalam (http://www.fgulen.org/conference-papers/, diakses tanggal 18 Desember 2010).

Bruckmayr, Philipp, "Fethullah Gulen and Islamic Literary Tradition", dalam Islamic in the Age of Global Challenges-Conference Proceedings.

Can, Eyup, "A Tour of Horizon with Fethullah Gulen (Fethullah Gulen Ille ufuk Turu)", dalam Zaman, Agustus, 1995.

Dewi, Apristia K., "Model Pendidikan Fethullah Gulen Layak Diapresiasi", dalam UIN Online, (http://www.uinjkt.ac.id/, diakses tanggal 23 Desember 2010).

Esposito, John L., Islam dan Politik, terj. Joesoef Sou'yb, Jakarta: Bulan Bintang, 1990.

, Ancaman Islam: Mitos atau Realiti?, terj. Nor Azita Omar, Kuala Lumpur: Institut Terjemahan Negara Malaysia Berhad, 2004.

Ebaugh, Helen Rose, The Gulen Movement: A Sociological Analysis of a Civic Movement Rooted in Moderate Islam, New York: Springer, 2010.

Fgulen.com, "Introducing Fethullah Gulen, dalam (www.gulenconference.net, diakses tanggal 29 Desember 2010).

Gulen, Fethullah, Toward a Global Civilization of Love and tolerance, Somerset: The light, 2004.

-----------, Towards the Lost Paradise, London: Truestar, 1996.

----------, Pearls of Wisdom, Fairfax: The Fountain, 2000.

Gulay, Erol Nazim, "The Theological Thought of Fethullah Gulen: Reconciling Science and Islam", dalam tesis For the Degree of 
Fethullah Gulen, Oleh: Aly Mashar

M.Phil in Oriental Studies/ Modern Middle Eastern Studies in St. Antony's College Oxford University, 2007.

Hodgson, Marshall G. S., The Venture of Islam: Conscience and History in a World Civilization, The Gunpowder Empires and Modern Times, Vol-3, Chicago and London: The University of chicago Press, 1974.

Nelson, Charles, "Fethullah Gulen: A Vision of Transcendent Education", dalam (www.gulenconference.net, diakses tanggal 29 Desember 2010).

Valkenberg, "Fethullah Gulen's Contribution to Muslim-Christian Dialogue in the Context of Abrahamic Cooperation, dalam (www.gulenconference.net, diakses tanggal 29 Desember 2010).

Yavuz, M. Hakan, Islamic Political Identity in Turkey, New York: Oxford University Press, 2003.

Zurcher, Erikj., Sejarah Modern Turki, terj. Karsidi D.R, Jakarta: PT. Gramedia, 2003. 